\title{
Enduring Logics of U.S. Foreign Aid during the Bush Administration
}

\author{
ChansOO CHO
}

Since 9/11 the Bush administration has made larger pledges than ever to the cause of promoting development and fighting HIV/AIDS in various corners of the globe. Foreign aid policy initiatives taken by the Republican president needed some explanations considering the GOP's longstanding dislike for foreign aid. One of the common answers was 9/11; the U.S. had to address the sources of discontent against itself by providing foreign development assistance to countries most vulnerable to terrorist infiltration. This paper argues that U.S. foreign aid during the Bush administration is not just a response to the spread of anti-American sentiments among failed and failing states but an outgrowth of foreign policy ideas that had shaped the liberal hegemon's vision of the new world order since the end of the Cold War. Particularly continuities between the Clinton and Bush administrations are stressed in terms of foreign policy ideas. Three themes of post-Cold War U.S. foreign policy are identified here: globalization, democracy promotion, and good governance. Globalization has been touted as the facilitator of economic prosperity through the liberalization of trade and capital flows. Democracy promotion has been endorsed as a long-term solution to security instability of the post-Cold War world. Good governance has been advanced as a yardstick by which to compare countries in their willingness and capability to be part of global community. Those major tenets of U.S. foreign policy affected the policy outlook of foreign aid in a way that makes less significant the difference between the Clinton and Bush administrations than is assumed.

Keywords: U.S. Foreign Aid, Bush, Clinton, Globalization, Democracy Promotion, Good Governance

\footnotetext{
Assistant Professor of International Studies, Kangnam University, San 6-2 Kugal-dong, Kiheung-gu, Yong-in, Kyunggi 446-702, Korea; Tel: 82-31-280-3826; E-mail: chansoocho@hanmail.net The author gratefully acknowledges the financial support of Kangnam University through its 2007 Faculty Research Grant. An earlier version of this paper was presented at the International Studies Association-West Annual Meeting, San Francisco, September 28-29, 2007. I wish to thank Shah M. Tarzi for helpful comments and suggestions. Thanks are also due to two reviewers for this journal.
} 


\section{INTRODUCTION}

$\mathrm{F}$

oreign aid has long been among the most widely used and most important policy means for the shapers of U.S. foreign policy during the second part of the twentieth century. Saving war-torn Europe from the looming threat of the Soviet Union had emerged as the highest priority in shaping the postwar world as American policymakers understood it to be desirable. Thus, America's first postwar foreign aid project, the Marshall Plan, was conceived and put into place. The plan turned out to be a success, and the U.S. government further expanded its foreign aid spending as the Cold War unfolded. In 1960, the amount of U.S. foreign aid reached the highest point in its history, providing 85 percent of global bilateral aid. Throughout the 1960s, the pattern did not change. In the 1970s, the European and Japanese economies recovered and began to surpass the U.S. economy in some aspects, and U.S. foreign aid did not increase in proportion to the inflation rate. As a result, the U.S. share of official development assistance (ODA) fell steadily and sharply, reaching a level of less than one fifth of total ODA in 1989.1 Although it is not that difficult to hear of an outcry condemning U.S. negligence of its global duties, the nation is still the world's largest food donor. The United States provided food aid in the amount of $\$ 1.2$ billion in 2004 to various recipients around the world. ${ }^{2}$ America's position within the ranks of major donor countries does not lend itself to an easy characterization, such as a generous versus a stingy giver. While other developed countries, particularly small European nations like Norway, have played a much larger role in the business of international largesse compared to the early postwar years, the United States remains the single biggest source of foreign aid of various kinds.

Foreign aid has served many different purposes, each of which was considered essential for defending U.S. national interest. Economic development, food aid, and military assistance altogether constituted the indispensable means by which America provided urgently needed protection to its allies during the Cold War. The collapse of communist regimes in Eastern Europe and the former Soviet Union, however, led to a subtle change in the environment under which U.S. foreign aid was planned and delivered. I characterize the change as subtle because one would not be able to see any wide fluctuations in the amount of U.S. foreign aid as defined in a standard way-"concessional resource transfers, one objective of which is to improve economic, social, political conditions in any foreign country"-during the past two decades. ${ }^{3}$ Figure 1 is an alternative estimate of U.S. foreign aid incorporating military aid that is not usually considered as a component of foreign assistance. It also shows that the United States has maintained an average of some $\$ 15.2$ billion throughout the period in which different U.S. policy priorities emerged such as combating a Second Cold War, staging covert action against insurgent guerillas, supporting reforms in post- 
Communist countries, and humanitarian intervention. While the first term of Clinton's presidency saw an easily discernible reduction in aid levels in large part due to the Democratic administration's emphasis on domestic issues, the change in the amount of tax dollars given to international causes was not huge when viewed in a longer historical perspective.

Figure 1. U.S. Foreign ECONOMIC AND MILITARY AID, 1980-2000 (IN MILLIONS OF U.S. DOLLARS)

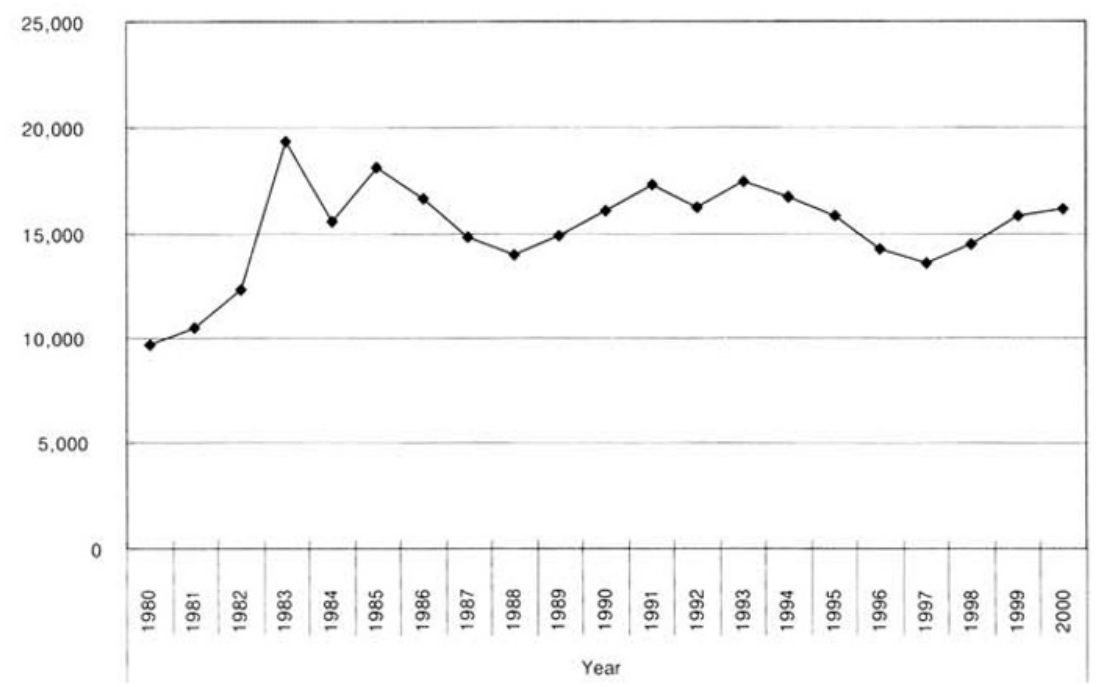

SOURCE: U.S. Bureau of the Census, various years

When the Bush administration took office in 2001, the prevailing expectation was that the Republican president would scale back the spending on international causes, let alone foreign aid. Indeed, Bush and his aides did not conceal their dislike for foreign aid. Despite these early policy forecasts, the Bush administration did not slash the amount of dollars spent on existing programs in a stark and dramatic way. Rather, Bush gave more weight to foreign aid by creating the Millennium Challenge Account (MCA) and proclaiming a huge increase in the funding to combat HIV/AIDS, to mitigate famine, and to deal with "complex emergencies." "Figure 2 shows relatively sharp increases in foreign aid after the inauguration of the Republican administration. Many accounts of U.S. foreign aid during the presidency of George W. Bush have focused on the relative importance of the September 11 attacks in explaining his stronger commitment toward foreign assistance. The most common puzzle is this: Why has the GOP president turned to a more internationalist aid policy despite the fact that he and his party had long been opposed to foreign aid? September 11 marks a turning point from which the Bush administration emerged with a new look 
at foreign aid. Extending relief to poverty-stricken countries might be viewed as contributing to eventual victory in the war on terror. Links between global terrorism and global poverty have been widely accepted among top policymakers inside the administration. For them, foreign aid in an era of the war on terror is another Marshall Plan to contain the zone of frustration.

While not debunking the evident importance of the September 11 attacks, this paper argues that the Bush administration's foreign aid policy has its origins far earlier than the attacks. More specifically, there are enduring logics of foreign aid that connect the Clinton and Bush administrations: globalization, democracy promotion, and good governance. As the main themes of post-Cold War U.S. foreign policy, the three have formed the basis of ideas about aid. Globalization has been touted as the facilitator of economic prosperity through the liberalization of trade and capital flows. Democracy promotion has been endorsed as a long-term solution to security instability of the post-Cold War world. Good governance has been advanced as a yardstick by which to compare countries in their willingness and capability to be part of global community. Those major tenets of U.S. foreign policy affected the policy outlook of foreign aid in a way that makes less significant the difference between the Clinton and Bush administrations than is assumed.

Figure 2. U.S. NON-MILITARY FOREIGN AID, 1990-2004 (IN MILLIONS OF U.S. DOLLARS)

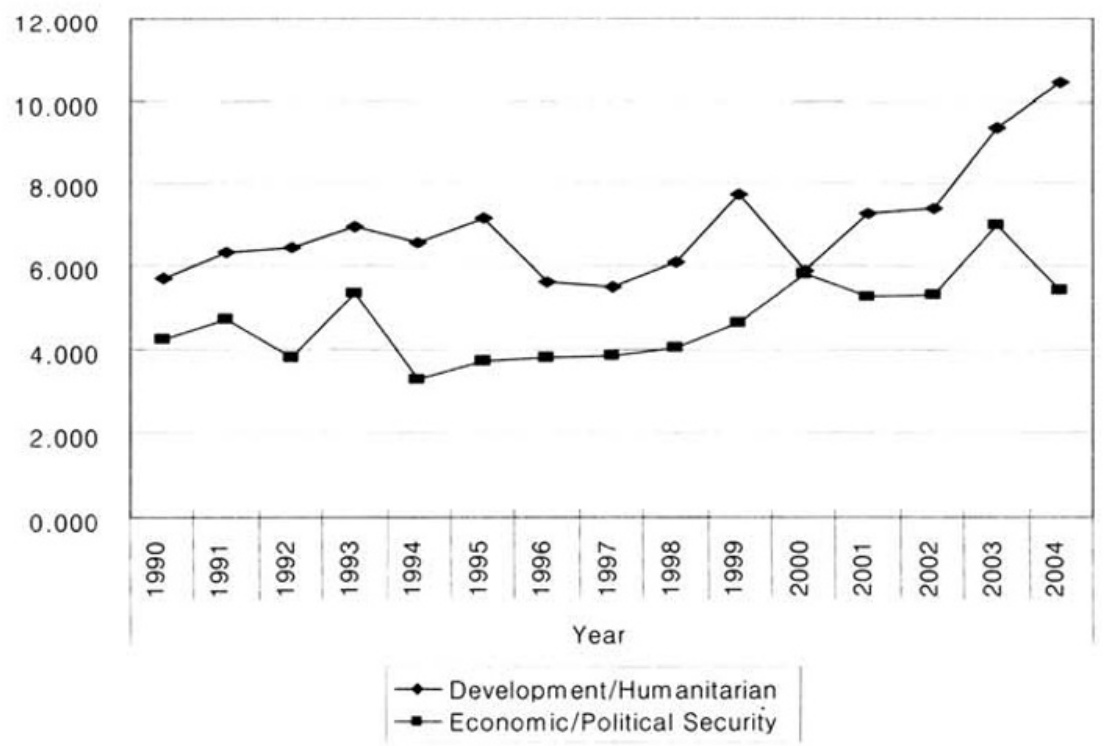

SOURCE: Tarnoff, Curt, and Larry Nowels. 2004. Foreign Aid: An Introductory Overview of U.S. Programs and Policy. CRS Report for Congress, Congressional Research Service, Library of Congress, p. 29. Iraq reconstruction efforts for 2003 (\$2.475 billion) and 2004 ( $\$ 18.439$ billion) not included here. 
The remainder of this paper is organized into four sections. Section II provides a theoretical discussion of how foreign aid policy is constructed by domestic politics. Section III looks into how the U.S. government has responded to post-Cold War demands for American foreign assistance by paying close attention to the Clinton administration. Section IV examines the extent to which the Bush administration has shaped its own foreign aid policy while keeping in line with the post-Cold War foreign policy themes. I conclude with a brief thought on the relationship between the domestic political economy and foreign policy.

\section{THEORETICAL ISSUES: FOREIGN AID CONSTRUCTED BY DOMESTIC POLITICS}

This section is devoted to advancing my views on the links between constructivism and the domestic politics approach in explaining international outcomes with special focus on foreign aid. Constructivism and the domestic politics approach are considered to have developed as separate methodological frameworks during the past two decades, even though the two are often mixed in many works from the field of international relations. 5 This paper stands on the premise that foreign policy ideas have much to do with the ways in which the domestic political economy is conceived and shaped. For the United States, which has the long history as a domestically oriented political economy, this joint approach is expected to provide a plausible account of the nation's policy choices.

Before elaborating on the joint approach it may be helpful to briefly review major alternative explanations. We have three major competing explanations of foreign aid: realism, liberalism, and constructivism. One may be tempted to add a moral or ethics approach to foreign aid to the list of possible explanations. Despite the subtle differences between constructivist and moral arguments, here the two approaches are lumped together in that both emphasize the role of ideas in shaping foreign policy.

From a realist view, aid to a sovereign state is little but a tool of foreign policy designed to exert influence on the target country to do what otherwise it would not do. As David A. Baldwin put it, "foreign aid is first and foremost a technique of statecraft. It is, in other words, a means by which one nation tries to get other nations to act in desired ways." 6 But there is a more theoretically important issue to be addressed by realists. Foreign assistance, whether it be economic or military, has the effect of allowing a target country to become stronger domestically and internationally. Thus, the realist puzzle in regard to foreign aid is not why states help other states by giving scarce resources but to what extent states achieve their desired goals by means of foreign assistance. Following the realist perspective, Bush's stronger commitment to foreign aid 
after September 11 should come as no surprise. The war on terror is an equivalent of the Cold War for American policymakers in that global terrorism poses a serious threat to U.S. interests just in the way international communism did. To conduct the war against the "phantom menace," however, requires a more complex and sophisticated approach to foreign aid as an essential means of U.S. grand strategy. While realists may diverge over the contents and direction of U.S. grand strategy, they would ask the same question for foreign aid: "Does it allow the United States to exercise influence over other states?" Then, to determine the degree to which the Clinton and Bush administrations look alike in foreign aid policy is not worthwhile.

Contrary to conventional wisdom, liberals, particularly liberal institutionalists, resemble realists in understanding aid to a sovereign state from an interest-based perspective. Liberals can be divided into two groups; one group stresses the commercial nature of a liberal international order, while the other highlights the difference republican (or democratic) states make in their behavior toward other states. Commercial liberals would argue that foreign aid is a win-win game in which all the participants receive benefits in one way or another due to its transfer function. Foreign aid, both economic and military, involves the transborder movement of goods and services; labor and capital; technology and knowledge. By giving aid to needy countries, donors can expect future returns on their "investment" in various forms, such as in the market for products, as the provider of raw materials, etc. In some countries where the glutted market is a problem, foreign aid offers an outlet for unsold or undersold inventory in the short run and thus allows glutted sectors to relocate to recipient countries in the long run. In sum, aid partially substitutes for trade. If, for any reasons, normal trading relations are unlikely in the near future, aid may turn out to be an efficient substitute. Commercial liberals would also count reputation as an economic value added from aid.

Republican or political liberals see a different side of the equation. They pay attention to the role of foreign aid in mitigating inequality and thereby consolidating democratic governments of recipient countries. While political liberals are not explicit about the relationship between democracy and the market, they tend to believe that economic well-being improves the likelihood of democratic survival in recipient countries. As a democracy is assumed to behave peacefully in foreign relations, aid can have the effect of pacifying interstate relations.

Another variant of liberalism stresses the effect of international cooperation brought about by foreign aid. As globalization proceeds, liberal institutionalists argue, issues in world politics are becoming more and more transnational, and that indicates the reduced ability of individual states to solve new kinds of problems. Major global issues like HIV/AIDS, desertification, transnational crimes and so forth require well-conceived coordination among affected and non-affected countries. From this perspective foreign aid is supposed to be multilateral; it 
is not a welfare program managed by a hegemon to pursue its grand strategy. Foreign aid is an essential means to achieve the end of maintaining and improving the quality of the global commons.

Constructivists offer a very different interpretation of foreign aid as an international phenomenon. They focus on the role of ideas in generating the impetus of an aid regime composed of major industrial nations. Some constructivists have responded to the criticism that ideas should be based on empirical reality by pointing to the link between domestic structures and transnational actors in pursuit of certain ideas. As Thomas Risse-Kappen aptly put it, "ideas do not float freely."7 This is the starting point at which a mix of constructivism and domestic politics approach may be conceived. Many scholars who focus on domestic variables in explaining international outcomes often confine themselves to rationalist or neo-utilitarian research programs. Domestic actors, whether individuals, groups, or institutions, are predominantly understood as driven by interests that are structural in nature. Economic interests clustering around classes or sectors provide a solid basis for collective action within the political arena.

There is an emerging literature on the domestic politics of foreign aid that emphasizes the role of interest groups and institutional arrangements. ${ }^{8}$ Though authors in this group have presented interesting findings-such as Milner and Tingley's observation that labor and liberal Democrats are more supportive of aid than they are of trade-they tend to remain confined within the limits of rationalist institutionalism. Like other foreign economic policy issues, aid is understood as an issue area in which social and economic groups see costs and benefits differently. While interest-based accounts of aid politics tell us much about how U.S. foreign aid is shaped by domestic actors, they tend to slight the fact that aid politics involves ideas as well as interests. Foreign assistance, especially economic aid, is not usually considered the best way to help out the needy people in the impoverished zones of the world. Here, the important question is: what makes such a negative view of foreign aid endure? Carol Lancaster offers an explanatory framework of foreign aid that focuses on domestic institutional arrangements and applies it to national case studies.? While sharing much of what Lancaster and other authors who drew on domestic politics variables have found, this paper gives more weight to the "social purpose" of the U.S. political economy that in turn shapes the way top policymakers understand the world.

Bipartisanship has long been cited as a characteristic of American foreign policy during much of the postwar years. That partisan politics must stop at water's edge has become one of the few golden rules abided by strategically thinking politicians, especially presidential hopefuls. As Bruce Bueno de Mesquita put it, "Those who criticize the position of the president are accused of seeking personal advantage at the expense of the nation's well-being."10 Bueno de Mesquita and many others who point to bipartisanship in foreign policy as political malaise, 
however, fail to realize that bipartisan foreign policy can have very different contents depending on the nature of its domestic social foundation. When bipartisanship was endorsed by Senator Arthur H. Vandenberg of Michigan at the start of the Cold War, it reflected a compromise struck between internationalist Democrats and "liberal" Republicans. In exchange for Republican support for U.S. international commitments, the then Democratic administration agreed to moderate the speed of welfare state expansion. 11 "In the middle of the twentieth century, the Democrats and the Republicans danced almost cheek to cheek in their courtship of the political middle." 12 But now it is said that the good old days are gone. Since the 2000 presidential election, blue states and red states have become part of the political vocabulary. Polarization of American politics has become a new academic magnet to attract researchers' attention.

This paper tries to turn the polarization thesis upside down by emphasizing the continuities between the Clinton and Bush administrations in their views on foreign aid policy. To demonstrate the continuities, I look into three themes of U.S. foreign policy which are closely related to the shift of the nation's domestic political economy.

\section{HOW U.S. FOREIGN AID HAS CHANGED SINCE THE END OF THE COLD WAR}

In this section, I look into how U.S. foreign aid has evolved since the end of the Cold War, particularly by examining the impact the Clinton administration left on the way in which foreign policy ideas were shaped. There are good reasons for focusing on the Clinton administration rather than the (George H. W.) Bush administration, though it was the latter that saw the rise of the United States as the sole superpower. On various occasions after the collapse of the Soviet bloc, George H. W. Bush frequently referred to the advent of a "new world order," in which U.S. leadership role in international affairs should be redefined. Redefining the U.S. role in the post-Cold War world involved striking an appropriate balance between resources and commitments. As the greatest threat to the nation and the world had become part of history, Congress was quick to stress the urgency of domestic issues, mostly about the economy. George $\mathrm{H}$. W. Bush himself tried to adjust to the changing demands on his administration, and his efforts were best exemplified by one of the most cited sound bites in American politics: "Read my lips, no new taxes." George H. W. Bush "became a prisoner of his own success." $13 \mathrm{He}$ failed not just to deliver on his 1988 promise but also to redefine the goals and direction of America's engagement with the new world. For example, the budget request for the fiscal year 1992 included spending plans on many non-de- 
fense programs in the amount of about $\$ 22$ billion that had been established during the Cold War. ${ }^{14}$

Rather, it was under the Clinton administration that a new direction of foreign aid was actively pursued. In 1998, Congress and the administration made a successful concerted effort to reduce the level of economic assistance to Israel and Egypt, the two largest recipients of U.S. strategic aid programs. ${ }^{15}$ Instead, more bilateral and multilateral economic assistance was earmarked for peacemaking efforts in Cyprus, Jordan, Northern Ireland, Bosnia and other Balkan countries, and the West Bank and the Gaza Strip. The Democratic president criticized his predecessor for "sid[ing] with the old geography of repression rather than with a new map of freedom." 16 Clinton was basically a domestically oriented president and downplayed the purpose of promoting security in the area of foreign aid. His foreign policy aides were advised to "keep the president informed" but not to "take too much of his time." 17 With few concrete policy measures in hand, during his presidency, particularly his second term, U.S. foreign assistance programs were diversified into many different regions and countries with strikingly different security and/or humanitarian issues.

In short, throughout the 1990 s the United States moved on to reformulate its foreign policy priorities in a way that brought to the fore the "objectives that would have been unthinkable $\cdots$ during the Cold War."18 Many conservative pundits like to chide the Clinton administration for making U.S. foreign policy (including foreign assistance) unfocused and unsteady, but they fail to realize that those eight years of Democratic rule left a lasting imprint on the ways the United States addressed major issues of world politics. Clinton's foreign aid policy was not as coherent as his critics may have wanted it to be, but it reflected the conviction that "[t]oday, instead of a well-defined threat to U.S. foreign policy, pervasive uncertainty faces the world's sole remaining superpower."19

\section{Globalization}

Globalization gained currency as the keyword of U.S. foreign policy during Clinton's first term. The 1990s were the decade when fierce competition among major industrial nations did not have to be mitigated by any systemic logics, like defending the Western bloc against the Soviet threat. Foreign aid was put higher on the list of Cold War policies to be reconsidered or simply phased out in the near future. There are some authors who raise a concern that foreign aid has been replaced by foreign direct investment since the $1990 \mathrm{~s} .{ }^{20}$ Still others voiced the concern that the Democratic administration would turn back the clock by endorsing a more isolationist approach to foreign aid. Emphasis was given to "manag[ing] the economy to preserve the ability of the nation to operate in the international system."21 
Increasing economic interdependence and the resultant porous borders during the 1990s coincided with the U.S. governmental shift from an executive-oriented to a Congress-oriented policy process. In the seeming absence of a systemic threat to U.S. interests, Congress began to reclaim its right to review major foreign policy issues. During the Cold War years, the U.S. legislature, purposely or out of a shared sense of threat, delegated many advisory and policy-forming powers to the executive branch, particularly to the president. Aside from national security and military issues, Congress more often than not gave the president and major executive agencies leeway to use various policy tools even in the areas of trade. Keeping the world safe from communism overshadowed what would otherwise have been a legitimate exercise of power on the part of Congress. Trade-security linkage was evident for much of the postwar period. ${ }^{22}$ After the victory in the Cold War, U.S. lawmakers came back with a vengeance to claim their rights to critically examine the way the executive spends on internationalist policies.

A good example of the Congress-oriented policy process can be found in the legislation passed in 1995 to restrict, if temporarily, the use of executive discretion for the purpose of "bailing out" the countries facing balance of payments problem s. ${ }^{23}$ Particularly, international financial rescues have become an equivalent of foreign aid that must be sharply cut or meticulously programmed as conditional grants. There are few better ways to describe the American sentiment toward financial crises abroad than the words of the very lawmaker who sponsored the bill against the Mexico bailout. The self-described socialist congressman Bernard Sanders (Independent-Vermont) in the wake of the East Asian financial crisis suggested that "the Asian Tigers fend for themselves." 24 Self-help became the cardinal virtue any financially responsible government must possess in an era of globalization.

\section{Democracy Promotion}

The end of the Cold War allowed the United States to openly propose the vision of a new world order based on international cooperation among democracies. The Clinton administration could afford to enjoy the luxury of pointing to non-democratic regimes, many of whom were traditional U.S. allies, as a possible source of instability in the post-Cold War world. Aid given to authoritarian regimes to prevent communist infiltration began to be subject to reassessment. "Aiding democracy abroad" 25 has become one of the pillars of U.S. foreign policy, replacing covert actions and support of anti-Communist dictatorships in the Third World. In the absence of a systemic threat that had constrained the liberal Democrats who felt uncomfortable with the U.S. ignorance of authoritarian regimes, Clinton could widely use the Wilsonian concepts of democracy and human rights. Created in 1983 as a private, nonprofit organization, the National Endowment for Democracy 
(NED) began to have influence on advocacy groups and academics in many transition and post-transition countries during the 1990s. One of its publications, the Journal of Democracy, has been cited as the main outlet of Washington's viewpoints about stable and sustainable democracy, which would in turn serve as a reliable bulwark against new security threats.

Democracy promotion has come to be viewed as the prime example of "soft power" exercised by the United States. Because of its strong normative connotations, democracy promotion has long been considered an "undiplomatic and impolite" way to deal with other countries. Furthermore, the U.S. government's ardent support of Third World dictatorships during the Cold War had the effect of narrowing the scope of soft power. Although Clinton and his top aides frequently used Wilsonian rhetoric, such as the "community of democracies," Carother's "semi-realism" would be a more accurate descriptor of the Democratic administration's stance toward democracy promotion. While the notion of "regime change" is often identified with Bush's unilateral policy of spreading democracy, particularly in the Arab world, Clinton was also credited with extending the policy of democracy promotion into the strategy of regime change in Yugoslavia. ${ }^{26}$

\section{Good Governance}

During the Clinton administration, good governance gained currency as one of the keywords of U.S. foreign policy in an era of increasing economic openness and interdependence. Unlike the Cold War pattern of aid delivery, increasing levels of interdependence have heightened the need to monitor the use of aid money in both the short and long run. One important characteristic of the "New" Democratic administration's foreign aid policy was that the shift in domestic politics played a larger role in refashioning the tools of American largesse. The idea of good governance was not devised for purely foreign policy purposes; rather, it became widespread among policy consultants as a set of recommendations to downsize and reshape the federal and other levels of U.S. government. 27

The link between good governance and foreign aid was made explicit when James Wolfensohn, as the president of the World Bank, began to direct the Bank's attention to the issue of corruption in 1996.28 Like other international organizations, the Bank had also been mired in a bureaucratic sentiment where lending and granting were made to corrupt recipient governments without some form of external monitoring. Almost at the same time, the International Monetary Fund (IMF) launched the "Heavily Indebted Poor Countries" (HIPC) plan as a response to mounting pressures upon itself to cancel the debts of African countries. The HIPC plan, however, required the recipient countries to engage in the IMF's recommended austerity measures for six years in order to qualify for a reduction in interest payments. 29 


\section{HOW THE BUSH ADMINISTRATION HAS PERCEIVED FOREIGN AID}

The Bush administration's policy views about how to realize U.S. grand strategy can be easily divided into two phases. The first phase was during the first nine months before the September 11 terrorist attacks, and this period was "characterized by a series of policy announcements that-whether by design or by accident-lent themselves to characterization as unilateralist, hostile to international treaties, institutions, and regime." 30 The second phase was characterized by U.S. responses to the attacks and highlighted by Bush's victory speech on May 2, 2003. This periodization, however, masks the continuities of U.S. foreign policy in many areas, particularly on aid. In the 2002 National Security Strategy of the United States, Bush put development on par with other traditional strategy areas: diplomacy and defense. Since the end of World War II, development has involved foreign aid, and the president's emphasis on development was a clear indicator of the administration's strong desire to reform aid programs in a forward-leaning fashion. As mentioned earlier, the 2001 terrorist attacks on the world's only superpower were definitely a turning point from which the Republican president began to give more weight to foreign assistance. But a close look at major documents of the Bush administration reveals that the policy ideas regarding foreign assistance resemble those prevalent during the Clinton administration. Globalization, democracy promotion, and good governance remain the favorite mantras American policymakers like to cite when they want to specify requisite conditions for aid.

\section{Globalization}

In his address to the Initiative for Global Development's 2006 National Summit, Bush made it clear that promoting free trade and fighting global poverty are intertwined. Introducing Susan Schwab, his recent pick for the post of U.S. Trade Representative, to the audience, he stated that "trade is one of the best ways to help lift people out of poverty." 31 Helping poor nations was understood as serving U.S. economic interest. "It's in the country's economic interest that we fight global poverty, because as developing nations grow in prosperity, they create better lives for their citizens and markets for U.S. products." The president evoked the examples of South Korea and India in touting the value of trade and even made the following quasi-statistical observation: "the strategy to defeat extreme poverty begins with trade. $\cdots$ The value of trade is more than ten times the value of foreign investment and foreign aid combined." Bush moved on to call for bipartisan support for trade agreements with developing countries. "[I]f we become a protectionist nation, if we lose our confidence and our capacity to compete in the global economy, it will make it much harder to achieve the common goal of reducing global poverty." 
Bush's endorsement of trade as a better way to deal with the persistence of extreme poverty in Africa was basically a repetition of Clinton's failed attempt to legislate the African Growth and Opportunity Act (AGOA), which was nicknamed "NAFTA for Africa." 32 Yet it must also be noted that the Bush administration had its own reason to push for trade liberalization more actively than its predecessor, at least in rhetoric. Bush and his advisors have a conviction that the perpetrators of the September 11 attacks were motivated to shake one of the pillars of U.S. preeminence: globalization. Just as the president encouraged his fellow Americans to shop more in the wake of the attacks, he invited a larger number of developing and undeveloped nations to the zone of free trade. Trade liberalization, as distinct from investment and grants, is not considered as a purely economic policy measure but instead as an essential tool to keep terrorism from infiltrating those nations.

A common subtheme of globalization with regard to foreign aid is the link between trade and aid. The Bush administration's stance toward the link is quite clear: "Foreign aid and trade and investment complement-rather than substitute for-each other." 33 This emphasis on the complementarity was remarkable considering the strength of Congressional Republicans' antipathy toward aid. Yet, Bush's emphasis on trade as a way to address the issue of global poverty in actuality led to worries about further reduction of antipoverty spending. 34

\section{Democracy Promotion}

It should come as no surprise that Bush has been described by Lawrence L. Kaplan as "the most Wilsonian president than Wilson himself." 35 In his address to Republican party delegates on September 2, 2004, Bush used the words "liberty" and "freedom" 34 times. Bush made clear his belief that "America is called to lead the cause of freedom in a new century." For the second-term president, eliminating tyranny in the twenty-first century must be put on the top of the list. Democracy promotion has become part of U.S. foreign policy since the 1990s, but Bush's stress on it has different elements than the ones that shaped the earlier administrations under his father and Clinton. While earlier emphasis on democracy and human rights had been based on a reasoning that the U.S. was now allowed to impose its cherished values on other states, the Bush administration viewed the spread of democracy as essential to defending U.S. interests in an era of global terrorism. Cooperation among like-minded states is not enough to prepare the U.S. for multifaceted threats posed by global networks of terrorists and rogue states. Democracy promotion has been replaced by regime change. 36 But, as mentioned earlier, the shift from democracy promotion to regime change was not the unique invention of Bush and his advisors who were wrongly labeled as "neoconservatives." What leftist critics of American primacy like to call "democratic imperialism" has been a staple of U.S. foreign policy as early as the 1980s. 
The Bush administration's turn to regime change, however, was not a direct response to the September 11 attacks. Rather, the idea of regime change came into existence well before the election of George W. Bush in 2000. As a candidate, Bush sent a clear message about a future foreign policy direction: "peace through strength." 37 The outgoing Clinton administration was harshly criticized for making U.S. leadership unfocused by sticking to popular but nebular terms like multilateralism. Democratic peace as a policy idea was basically embraced by Bush but with a crucial Republican twist. For Bush as a conservative politician, democratic peace is a moral choice; neither is it rhetoric of using less hard power nor is it a normative idea about world affairs. The Bush administration understood democratic peace as a national security strategy in which autocratic regimes are supposed to be eliminated by every possible means. As Moens rightly pointed out, "Bush thinks and acts in terms of values." 38 While U.S. foreign policy during the Clinton administration advanced a package of globalization and democratic peace, Bush emphasized the independent value of democracy as a foreign policy goal. The Republican president "accepted Woodrow Wilson's view that the United States's foreign policy should seek to promote its values abroad as well as its interests." 39 That's why Bush seems to make a larger commitment to foreign assistance for the purpose of spreading democracy in troubled regions.

Reflecting the president's will to spread democracy, overall funding for this "political aid" 40 has increased by 20 percent since FY 2001.41 In his address to the Initiative for Global Development's 2006 National Summit, Bush said, "[m]any of the worst dictatorships are some of the [sic] poorest nations." 42 In tune with the president's policy direction, USAID launched a special program for Afghanistan and Iraq soon after 9/11.43

\section{Good Governance}

Although the idea of good governance has long been associated with some major policymakers of the Clinton administration, particularly Al Gore, the Bush administration has formulated and implemented more specific policy measures to encourage recipient countries to match development progress with the institutional capacity to sustain themselves. This agenda is closely related to that of democracy promotion because good governance is often considered as a natural outcome of democratic politics. The Bush administration reshaped USAID programs in a way that prioritizes examining the "causes of the fragility rather than the symptoms" of the recipient countries. ${ }^{44}$ Transformational development is the keyword that gives direction to current U.S. foreign aid policy. While traditional aid programs have focused on development aid programs aimed at short-term results, transformational development encourages recipient countries to "transform [themselves] $\cdots$ through far-reaching, fundamental changes in 
institutions of governance, human capacity, and economic structure and social progress without depending on foreign aid." 45 This is in tune with Bush's emphasis on recipient countries' self-help efforts. Moreover, unlike the programs aimed at democracy promotion, good governance programs are often considered as "low-cost interventions that include extensive training sessions for government officials, the media, and other elements of civil society." 46

However, if the Bush administration's idea of good governance served just as a cover for switching aid money to the areas in which the United States had more at stake, there would be no significant way of distinguishing between the Clinton and Bush administrations. The latter's emphasis on good governance is closely related to its preoccupation with the notion of regime change. It is very clear from a series of announcements made by the president and his top aides that the Bush administration put aid on par with military options as a way to pressure foreign governments to reform themselves.

The creation of the Millennium Challenge Account was justified on the grounds that U.S. foreign aid would be extended selectively to countries meeting performance requirements in the areas of "budget deficits, trade policy, immunization rates, primary-school completion rates, control of corruption, and the protection of civil liberties." 47 At first, the MCA funds were to be distributed mostly to failed, failing, and fragile states, but starting in 2006, middle-income countries began to be included on the target list. Although it can be interpreted as a sign of the politicization of the MCA, it also illustrates how seriously the administration takes the linkage between foreign aid and good governance.

One other trait of U.S. foreign aid policy during the Bush administration is its emphasis on the role of private and nongovernmental organizations in expanding the scope of humanitarian assistance. It is not just a strategy of passing the buck onto transnational civil society, as the U.S. often has done so in dealing with its allies. During the Cold War, there was only a limited role to play for NGOs, and American policymakers viewed them as cumbersome and even undermining U.S. interests by leaning toward politically naïve, humanitarian causes. As the systemic confrontation between the two blocs came to an end, heretofore repressed aspects of ethnic conflict and new kinds of global issues came to the fore. The United States and other Western donors reckoned that the transnational nature of the so-called "global" issues like SARS, organized crime, environmental degradation and so on made NGOs more suitable for addressing the issues and delivering aid than states.

Given the delicate nature of ethnic conflict and the continuing presence of great powers like Russia, the U.S. government understood that nongovernmental advocacy groups and other private voluntary organizations were much better on the job of providing program and project assistance. Most conflicts and disputes in the 1990s and early 2000s were civil in nature, and that rendered much more complicated the business of delivering aid to affected regions and communities. 
Steven Holtzman provides a succinct account of how complex the issues are: "Aside from damage to physical infrastructure, the state apparatus and economic potential $\cdots$, it is the fabric of societies which has been torn and in many ways transformed. Conflict alters societies, creating incentives, patterns of behavior and institutional legacies which influence the reconstruction process." 48 Of particular importance to the U.S. was the possibility of strengthening "program assistance" by allowing NGOs to apply their expertise to recipient countries. The U.S. government has an incentive to use NGOs as an agent, especially when it has to deal with the cases of state failure where governments themselves are the problem. Because Western donors, including the United States, do not want to bother to handle inept and/or corrupt governments, NGOs and other service providers were brought in to deliver aid directly to affected populations. 49

\section{CONCLUSION}

Before September 11, the Bush administration's foreign policy had a nice and clear framework for action toward the world. From the viewpoint of the Republican president, the complex terrain facing the sole superpower required a more unilateralist move. The United States was to adjust its military deployment to the unstably changing environment, and preventive measures including going to war were widely contemplated. Although the doctrine of preventive war is not new in the history of U.S. foreign relations, 50 the Bush administration incorporated the idea into concrete policy measures more actively than any other administration in U.S. history. Having said that, the impact of September 11 on Bush's policy choices should not be exaggerated. "September 11 did more to reaffirm Bush's view of the world than to transform it." 51

The main thrust of this paper is that the Bush administration has formulated and implemented foreign aid policy in order to achieve larger goals similar to those pursued by the Clinton administration. The received wisdom about Bush's foreign policy is that the president's perspective on world politics represented "ABC-Anything But Clinton." 52 This paper tried to show that Bush had much more in common with Clinton than is generally assumed. I have picked three themes of U.S. foreign policy that had been in place since the end of the Cold War. Globalization, democracy promotion, and good governance are the shared ideas of the two administrations in engaging in world affairs. This argument is at odds with the prevailing notion of polarization in American politics, according to which Bush's foreign assistance policy should have been quite different from his predecessor's.

As Charles Kupchan and Peter Trubowitz put it, "today's partisan wrangling over foreign policy is the historical norm; it is the bipartisanship of the Cold War that was the anomaly." 53 However, many authors including Kupchan and 
Trubowitz have failed to highlight the structural reality that Democrats and Republicans had come to resemble each other in terms of how they envision the direction of the U.S. political economy. As early as the 1980s, the Democratic party began to make an ideological shift toward the center after the bitter experiences of inflation and slow growth during the Carter administration. This is not to say that executive Republicans have not changed all that much while the New Democrats moved to the right to woo suburban middle-class voters in the metropolitan areas. Although I do not entirely accept Kupchan and Trubowitz's evaluation of how divided America is, their "from the inside out" perspective is similar to the approach taken here. Reflecting on how bipartisanship in foreign policy had been formed at the conclusion of World War II, Kupchan and Trubowitz include "changes in the nation's political landscape" as an important source of "bipartisan cooperation." 54

In this essay, I have given attention to the links between the domestic political economy and foreign policy. While the "vital center" coalition during the early postwar period was an internationalist compromise between two conflicting views on the domestic political economy, the current dissension over the form of America's leadership role masks the consensus among the two major political parties over the deep-seated structure of the evolving world political economy. Foreign aid exemplifies what the emerging bipartisanship is all about.

\section{REFERENCES}

Baldwin, David A. 1966. Foreign Aid and American Foreign Policy: A Documentary Analysis. New York: Praeger.

Berman, Larry and Emily O. Goldman. 1996. Clinton's Foreign Policy at Midterm. In The Clinton Presidency: First Appraisals, ed. Colin Campbell and Bert A. Rockman, 290-324. Chatham, N.J.: Chatham House Publishers.

Brainard, Lael. 2001. Globalization in the Aftermath: Target, Casualty, Callous Bystander? Analysis Paper \#12, America's Response to Terrorism, November. Broz. J. Lawrence. 2005. Congressional Politics of International Financial Rescues. American Journal of Political Science 49: 479-496.

Brynen, Rex. 2000. A Very Political Economy: Peacebuilding and Foreign Aid in the West Bank and Gaza. Washington, D.C.: United States Institute of Peace. Bueno de Mesquita, Bruce. 1999. Why Politics Should Not Stop at Water's Edge. The Daily Report 15(November). Available at http://www.hoover.org/pubaffairs/dailyreport/archive/2856921.html. (accessed on Sept. 1, 2007).

Bueno de Mesquita, Bruce and Alastair Smith. 2006. A Political Economy of Aid. Mimeo.

Carothers, Thomas. 1999. Aiding Democracy Abroad: The Learning Curve. Washington, D.C.: Carnegie Endowment for International Peace. 
Daalder, Ivo H. and James M. Lindsay. 2003. America Unbound: The Bush Revolution in Foreign Policy. Washington, D.C.: Brookings Institution Press.

Encarnación, Omar G. 2003. Beyond Civil Society: Promoting Democracy after September 11. Orbis 47(4).

Fordham, Benjamin O. 1998. Building the Cold War Consensus: The Political Economy of U.S. National Security Policy, 1949-1951. Ann Arbor: University of Michigan Press.

Guyatt, Nicholas. 2000. Another American Century? The United States and the World after 2000. New York: Zed Books.

Heineman, Ben W., Jr., and Fritz Heimann. 2006. The Long War against Corruption. Foreign Affairs 85: 75-86.

Hyland, William G. 1999. Clinton's World: Remaking American Foreign Policy. Westport, Conn.: Praeger.

Isaak, Robert A. 2005. The Globalization Gap: How the Rich Get Richer and the Poor Get Left Further Behind. Upper Saddle River, N.J.: Prentice Hall/Financial Times.

Katzenstein, Peter J. 1990. Analyzing Change in International Politics: The New Institutionalism and the Interpretive Approach. Köln: Max-Planck Institut für Gesellschaftsforschung.

, ed. 1996. The Culture of National Security: Norms and Identity in World Politics. New York: Columbia University Press.

Krueger, Anne O. 1993. Economic Policies at Cross-Purposes: The United States and Developing Countries. Washington, D.C.: Brookings Institution.

Kupchan, Charles A., and Peter L. Trubowitz. 2007. Grand Strategy for a Divided America. Foreign Affairs 86: 71-83.

Lancaster, Carol. 2000. Transforming Foreign Aid: United States Assistance in the $21^{s t}$ Century. Washington, D.C.: Institute for International Economics.

. 2007. Foreign Aid: Diplomacy, Development, Domestic Politics. Chicago: University of Chicago Press.

Lancaster, Carol, and Ann Van Dusen. 2005. Organizing U.S. Foreign Aid: Confronting the Challenges of the Twenty-First Century. Washington, D.C.: Brookings Institution Press.

Litwak, Robert S. 2007. Regime Change: U.S. Strategy through the Prism of 9/11. Washington, D.C.: Woodrow Wilson Center Press.

McCarty, Nolan, Keith T. Poole, and Howard Rosenthal. 2006. Polarized America: The Dance of Ideology and Unequal Riches. Cambridge: MIT Press.

Milner, Helen V. and Dustin H. Tingley. 2006. The Domestic Politics of Foreign Aid: American Legislators and the Politics of Donor Countries. Paper presented at the Annual Meeting of the American Political Science Association, Philadelphia, PA, September.

Moens, Alexander. 2004. The Foreign Policy of George W. Bush: Values, Strategy, and Loyalty. Aldershot, Hunts: Ashgate. 
New York Times, The. 2006. U.S. Foreign Aid, Revised. 26(November).

Osborne, David, and Ted Gaebler. 1992. Reinventing Government: How the Entrepreneurial Spirit is Transforming the Public Sector. Reading, Mass.: Addison-Wesley.

O'Sullivan, Meghan L. 2003. Shrewd Sancations: Statecraft and State Sponsors. Washington, D.C.: Brookings Institution Press.

Radelet, Steven. 2003. Bush and Foreign Aid. Foreign Affairs 82: 104-117. Risse-Kappen, Thomas. 1994. Ideas Do Not Float Freely: Transnational Coalitions, Domestic Structures, and the End of the Cold War. International Organization 48: $185-214$.

Robinson, William I. 1996. Promoting Polyarchy: Globalization, US Intervention, and Hegemony. Cambridge: Cambridge University Press.

Sanders, Bernard. 1997. Let the Asian Tigers Fend for Themselves. Los Angeles Times 10(December).

Sewell, John W. 1992. Foreign Aid for a New World Order. In U.S. Foreign Policy after the Cold War, ed. Brad Roberts, 181-191. Cambridge: MIT Press. Skidmore, David, ed. 1997. Contested Social Orders and International Politios. Nashville: Vanderbilt University Press.

Tarnoff, Curt, and Larry Nowels. 2004. Foreign Aid: An Introductory Overview of U.S. Programs and Policy. CRS Report for Congress, Congressional Research Service, Library of Congress.

Trachtenberg, Marc. 2007. Preventive War and U.S. Foreign Policy. Security Studies 16: 1-31.

U.S. Agency for International Development. 2004. U.S. Foreign Aid: Meeting the Challenges of the Twenty-first Century. Washington, D.C.: U.S. Agency for International Development.

. 2005. Fragile States Strategy. Washington, D.C.: U.S. Agency for International Development.

Verdier, Daniel. 1994. Democracy and International Trade: Britain, France, and the United States, 1860-1990. Princeton: Princeton University Press.

White House, The. 2007. President Attends Initiative for Global Development's 2006 National Summit. Available at http://www.whitehouse.gov/news/releases/ 2006/06/20060615.html. (accessed on September 2, 2007).

\section{ENDNOTES}

'Anne O. Kruege. 1993. Economic Policies at Cross-Purposes: The United States and Developing Countrie (Washington, D.C.: Brookings Institution), 48-49.

2 Carol Lancaster and Ann Van Duse. 2005. Organizing U.S. Foreign Aid: Confronting the Challenges of the Twenty-First Century (Washington, D.C.: Brookings Institution Press), 16.

${ }^{3}$ Carol Lancaste. 2000. Transforming Foreign Aid: United States Assistance in the $21^{g}$ Century (Washington, D.C.: Institute for International Economics), 9: 14.

${ }_{5}^{4}$ Steven Radele. 2003. Bush and Foreign Aid. Foreign Affair 82: 104

5 For example, see Peter J. Katzenstein. 1990. Analyzing Change in International Politics: The New Institutionalism and the Interpretive Approacln (Köln: Max-Planck Institut für Gesellschaftsforschung); 
David Skidmore, ed. 1997. Contested Soxial Orders and International Politic (Nashville: Vanderbilt University Press).

'David A. Baldwi. 1966. Foreign Aid and American Foreign Policy: A Documentary Analysis (New York: Praeger), 3.

${ }^{7}$ Thomas Risse-Kappe. 1994. Ideas Do Not Float Freely: Transnational Coalitions, Domestic Structures, and the End of the Cold War. International Organizatio 48: 185-214.

${ }^{8}$ Bruce Bueno de Mesquita and Alastair Smit. 2006. A Political Economy of Aid. Mimeo; Helen V. Milner and Dustin H. Tingley. 2006. The Domestic Politics of Foreign Aid: American Legislators and the Politics of Donor Countries. Paper presented at the Annual Meeting of the American Political Science Association, Philadelphia, PA, September.

9 Carol Lancaste. 2007. Foreign Aid: Diplomacy, Development, Domestic Politics (Chicago: University of Chicag Press).

${ }^{10}$ Bruce Bueno de Mesquit. 1999. Why Politics Should Not Stop at Water's Edge. The Daily Report 15(November). Available at http://www.hoover.org/pubaffairs/dailyreport/archive/2856921.htm. (accessed on Sept. 1, 2007).

"Benjamin O. Fordham. 1998. Building the Cold War Consensus: The Political Economy of U.S. National Security Policy, 1949-1945 (Ann Arbor: Uiversity of Michigan Press), 9-10.

${ }^{12}$ Nolan McCarty, Keith T. Poole and Howard Rosentha. 2006. Polarized America: The Dance of Ideology and Unequal Riches (Cambridg: MIT Pres), 1.

${ }^{13}$ William G. Hyland. 1999. Clinton's World: Remaking American Foreign Polics (Westport, Conn.: Praeger), 6.

${ }^{14}$ John W. Sewel. 1992. Foreign Aid for a New World Order. In U.S. Foreign Policy after the Cold War, ed. Brad Roberts (Cambridge: MIT Pres), 182.

15 Carol Lancaster. 2007. 18.

${ }_{17}^{16}$ Quoted in William G. Hyland. 1999, 18. Emphasis added.

17 Ibid., 18.

${ }^{18}$ Meghan L. O'Sullivan. 2003. Shrewd Sancations: Stateraft and State Sponsors (Washington, D.C.: Brookings Institution Press), 15.

${ }^{19}$ Larry Berman and Emily O. Goldman. 1996. Clinton's Foreign Policy at Midterm. In The Clinton Presidency: First Appraisals, ed. Colin Campbell and Bert A. Rockman (Chatham, N.J: Chatham House Publisher), 293.

${ }^{20}$ Robert A. Isaak. 2005. The Globalization Gap: How the Rich Get Richer and the Poor Get Left Further Behind (Upper Saddle River, N.J.: Prentice Hall/Financial Time), 73-74.

${ }^{21}$ Larry Berman and Emily O. Goldma. 1996, 293.

${ }^{22}$ Daniel Verdie. 1994. Democracy and International Trade: Britain, France, and the United States, 1860-1990 (Princeton: Princeton University Press).

${ }^{23}$ J. Lawrence Broz. 2005. Congressional Politics of International Financial Rescues. American Journal of Political Science 49: 479-480.

${ }^{24}$ Bernard Sanders. 1997. Let the Asian Tigers Fend for Themselves. Los Angeles Times, December 10.

${ }^{25}$ Thomas Carothers. 1999. Aiding Democracy Abroad: The Learning Curve (Washington, D.C.: Carnegie Endowment for International Peace).

${ }^{26}$ Ivo H. Daalder and James M. Lindsay. 2003. America Unbound: The Bush Revolution in Foreign Policy (Washington, D.C.: Brookings Institution Press), 14.

${ }^{27}$ David Osborne and Ted Gaebler. 1992. Reimenting Govenment: How the Entrepreneurial Spirit is Transforming the Public Sector (Reading, Mass.: Addison-Wesley)

${ }^{28}$ Ben W. Heineman, Jr. and Fritz Heiman. 2006. The Long War against Corruption. Foreign Affair 85: 78.

${ }^{29}$ Nicholas Guyatt. 2000. Another American Century? The United States and the World after 2000 (New York: Zed Books), 22.

${ }^{30}$ Lael Brainard. 2001. Globalization in the Aftermath: Target, Casualty, Callous Bystander? Analysis Paper \#12, America's Response to Terrorism, November.

${ }^{31}$ The White House. 2006. President Attends Initiative for Global Development's 2006 National Summit. Available at http://www.whitehouse.gov/news/releases/2006/06/20060615.html (accessed on Sept. 2, 2007).

${ }^{32}$ Nicholas Guyatt. 2000, 24.

${ }^{33}$ U.S. Agency for International Development. 2004. U.S. Foreign Aid: Meeting the Challenges of the Twenty-first Century. Washington, D.C.: U.S. Agency for International Development, 11.

${ }^{34}$ U.S. Foreign Aid, Revised. New York Times, November 26, 2006.

${ }^{35}$ Omar G. Encarnación. 2003. Beyond Civil Society: Promoting Democracy after September 11. Orbis

47.
${ }^{36}$ Robert S. Litwak. 2007. Regime Change: U.S. Strategy through the Prism of $9 / 11$ (Washington, D.C.: Woodrow Wilson Center Press).

${ }^{37}$ Alexander Moens. 2004. The Foreign Policy of George W. Bush: Values, Strategy, and Loyalty (Aldershot, Hunts: Ashgate, 87. 
${ }^{8}$ Ibid., 2

39 Ivo H. Daalder and James M. Lindsay. 2003. 36.

${ }^{40}$ William I. Robinson. 1996. Promoting Polyardy: Globalization, US Intervention, and Hegemony (Cambridge: Cambridge University Press), 73.

${ }^{41}$ Curt Tarnoff and Larry Nowels. 2004. Foreign Aid: An Introductory Overview of U.S. Programs and Policy. CRS Report for Congress, Congressional Research Service, Library of Congress, 12.

${ }^{42}$ The White House. 2006.

${ }^{43}$ U.S. Agency for International Development. 2005. At Freedom's Frontiers: A Democracy and Governance Strategic Framework. Washington, D.C.: U.S. Agency for International Development, 1.

${ }^{14}$ U.S. Agency for International Development. 2005. Fragile States Strategy. Washington, D.C.: U.S. Agency for International Development, 6.

${ }_{46}^{4}$ U.S. Agency for International Development. 2004. 14.

${ }^{46}$ Curt Tarnoff and Larry Nowels. 2004. 9-6.

${ }^{47}$ Steven Radelet. 2003, 111.

${ }^{48}$ Quoted in Rex Brynen. 2000. A Very Political Economy: Peacebuilding and Foreign Aid in the West Bank and Gaza (Washington, D.C.: United States Institute of Peace), 8-9.

${ }^{49}$ Steven Radelet. 2003, 115.

${ }^{50}$ Marc Trachtenberg. 2007. Preventive War and U.S. Foreign Policy. Security Studies 16: 1-31.

51 Ivo H. Daalder and James M. Lindsay. 2003. 79.

52 Ibid., 37.

${ }^{53}$ Charles A. Kupchan and Peter L. Trubowitz. 2007. Grand Strategy for a Divided America. Foreign Affairs 86: 73 .

${ }^{54}$ Ibid., 75. 